\title{
Acute urinary retention accompanied by bladder stones
}

\section{Akut Üriner Retansiyon Ille Mesane Taşı Birlikteliği}

\author{
Engin $\mathbb{K}_{0}$ lüikçuï ${ }^{1}$, Serhat Koyuncu ${ }^{2}$
}

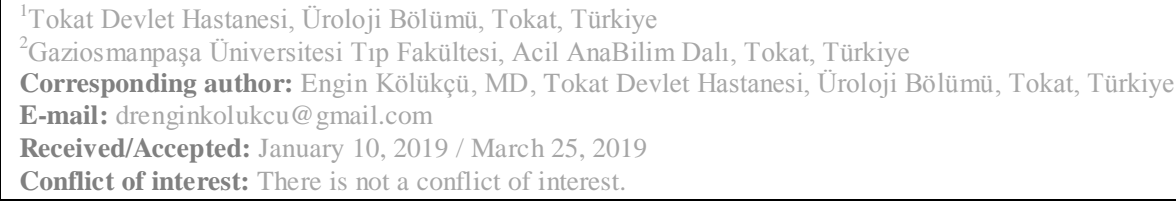

\section{SUMMARY}

Objective: The aim of this study was to evaluate patients presented with acute urinary retention and found to have bladder stones.

Method: The records of 27 adult male patients presented to the emergency clinic with acute urinary retention between October 2011 and December 2017 were examined retrospectively. Patients' age, stone size, etiologic factors and treatment modalities were analyzed.

Results: All patiens were male and the mean age was $60.41 \pm 15.71(19-86)$ years. The main complaint of all patients was acute urinary retention. In addition, one patient had a feeling of fullness in the rectum, three had bilateral flank pain, five had high fever and four had renal failure. A total of nine (33.3\%) patients were found to have stones localized in anywhere in the urinary tract along with bladder stones. All patients who had urogenital pathology pose a risk for bladder stone formation. The most common pathology was prostatic hyperplasia seen in 19 (70.4\%) patients.

Conclusions: We are of the opinion that it is very important to consider bladder stones among the preliminary diagnoses in patients presenting with acute urinary retention.

Keywords: Acute urinary retantion, bladder, stone

\section{ÖZET}

Amaç: Çalışmamızda akut üriner retansiyon ile başvuran ve mesane taşı tespit edilen hastaların değerlendirilmesi amaçlanmıştır.

Yöntem: Ekim 2011 ve Aralık 2017 tarihileri arasında acil kliniğine akut üriner retansiyon ile bașvuran ve mesane taș1 tespit edilen 27 erişkin erkek hastanın dosyaları retrospektif olarak incelendi. Hastaların yaşı, taş boyutları, etiyolojik faktörleri ve uygulanan tedavi modaliteleri analiz edildi.

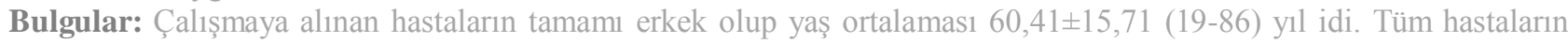
ana başvuru şikayeti akut idrar retansiyonu idi. Ek olarak hastaların 1'inde rektal dolgunluk hissi, 3'ünde iki taraflı yan ağrısı, 5'inde yükssek ateş ve 4'ünde böbrek yetmezliği tablosu izlendi. Toplam $9(\% 33,3)$ hastada mesane taşı ile beraber üriner sistemin herhangi bir lokalizasyonunda taş tespit edildi. Tüm hastalarda mesane taş1

oluşumuna neden olacak ürogenital patoloji izlendi. En sık tespit edilen patoloji $19(\% 70,4)$ hastada izlenen prostat hiperplazisi idi.

Sonuç: Akut üriner retansiyon ile başvuran hastalarda mesane taşlarının ön tanılar arasında düşünülmesinin son derece önemli olduğu kanaatindeyiz.

Anahtar sözcükler: Akut üriner retansiyon, mesane, taş

\section{INTRODUCTION}

Acute urinary retention is an urologic emergency characterized by a sudden inability to pass urine even though the bladder is full (1). The pathophysiology of acute urinary retention is complex and multifactorial. Pathology may occur in the bladder wall or in the motor innervation to the detrusor muscles, as well as in cases where the urine flow is mechanically blocked. The etiology of acute urinary retention includes many clinical conditions such as benign prostatic hypertrophy, urethral strictures, pelvic organ prolapses, pelvic traumas, lower urinary tract stone diseases, 
diabetic neuropathy, multiple sclerosis, central nervous system tumors, bladder neck stenosis, spinal cord injury, bladder and prostate cancers (1-3). Most patients with acute urinary retention are elderly men. The main reason for this condition is prostatic hyperplasia as its prevalence rises with increasing age. Approximately $10 \%$ of men in their 70s and nearly $33 \%$ in their 80 s will develop acute urinary retention at least for once (4). A clinical study in the United States showed that the overall incidence of acute urinary obstruction was between 4.5 and 6.8 per 1000 men (5).

The history of bladder stones dates back to ancient times (6). The diagnosis is usually made during the investigation of lower urinary tract complaints in adult patients. However, the cases may be associated with various clinical outcomes such as acute urinary retention, renal failure, and urosepsis $(7,8)$. Endemic bladder stones are often observed at early ages in relation to dietary habits. However, bladder stones are secondary to bladder outlet obstruction in western societies, especially in men, as the frequency increases with advancing age (9).

The number of previous publications evaluating bladder stones in patients presenting with acute urinary retention seems to be highly limited. In this retrospective study, we aimed to investigate adult male patients who presented with acute urinary retention and diagnosed with bladder stones.

\section{MATERIAL AND METHODS}

We retrospectively analyzed the records of 27 adult male patients presented to the emergency clinic with acute urinary retention and diagnosed with bladder stones in the analysis following the interventions performed between October 2011 and December 2017. The evaluation was carried out through medical history form, physical examination, urinalysis, routine biochemical tests, direct urinary system graphy, urinary ultrasonography, non-contrast tomography and cystourethroscopy. Our retrospective analysis included age, stone size, etiologic factors and treatment modalities of the patients were retrospectively analyzed. Patients with missing data were excluded from the study. The study was carried out in Tokat State Hospital (Ethics Committee number: 18-KAEK-268).

In the first step, we considered urethral catheter, for urinary diversion. When urethral catheterization failed, a suprapubic cystostomy catheter was applied percutaneously. Before the cystostomy procedure, all patients underwent a detailed ultrasonography for contraindications. There was no hindrance for performing the procedure. Urine cultures were obtained from all patients, and broad-spectrum antibiotics were started.

All the patients underwent cystourethroscopy under elective conditions to confirm the diagnosis and to analyze the etiological factors. The endourological interventions were performed by applying a $2 \%$ lidocaine gel intraurethral in a lithotomy position via a 0 -degree lens passing through a 19.5 Fr or 22 Fr endoscope. The treatment procedures were shaped by the size of the stone, the general condition of the patient and the etiological factors. The treatment involved internal urethrotomy, endoscopic bladder neck incision, transurethral prostatectomy, open prostatectomy, endoscopic and open cystolithotomy procedures. All these procedures were performed under sterile conditions with general or spinal anesthesia.

\section{Statistical Analysis}

SPSS (Statistical Package for the Social Sciences in PASW Statistics, SPSS Inc., Chicago, IL, USA) version 18.0 software was used for data analysis. Continuous data of patients were expressed as the mean \pm standard deviation (minimum-maximum) whereas categorical data were expressed as frequencies and percentages (\%). The Pearson chi-square test or Fisher's exact test was used to comparing proportions for detected microorganisms, stone sizes and etiological factors. Fisher's exact test was used when the expected value in one or more cells was less than 5.0 in the crosstab. A p value of less than 0.05 was considered statistically significant.

\section{RESULTS}

Twenty-seven patients presented with acute urinary retention and diagnosed with bladder stones were included in the study. All of the patients included in the study were men whose age range was 19-86 years and the mean age was $60.41 \pm 15.71$ years. The main symptom noted in all patients was acute urinary retention. Besides, one patient experienced a feeling of rectal fullness, three had bilateral flank pain, five had high fever and four had renal failure. Urinary tract infection was detected in $16(59.3 \%)$ cases. The distribution of microorganisms in culture-positive urine samples demonstrated that ten patients had Escherichia coli, three had Klebsiella pneumoniae, two had Proteus mirabilis and one 
patient was found to have Candida albicans (Table

$1)$.

Table 1: Numbers and percentages of isolated microorganism

\begin{tabular}{|l|l|l|l|}
\hline Pathogen & $\mathrm{n}$ & $\%$ & ${ }^{\mathrm{a}} \mathrm{P}$ value \\
\hline Escherichia coli & 10 & 62.5 & \\
\cline { 1 - 3 } Klebsiella pneumoniae & 3 & 18.75 & \\
\cline { 1 - 3 } Proteus mirabilis & 2 & 12.5 & \multirow{2}{*}{$\mathrm{P}<0.001$} \\
\cline { 1 - 2 } Candida albicans & 1 & 6.25 & \\
\hline
\end{tabular}

${ }^{a}$ : Fisher exact test, *statistically significant

Urine culture was positive in $16(59.3 \%)$ patients

Twenty of the patients evaluated in the study were observed to have only one stone, while four had multiple stones. Of the remaining three patients, one had two stones and two had three stones. The mean stone size was $50.96 \pm 17.33$ (20-80) $\mathrm{mm}$. Nine $(33.3 \%)$ of the 27 patients were found to have stones anywhere in the the urinary tract together with bladder stones. Of these nine patients, three had renal stones, five had urethral stones and one had proximal ureteral stones.

In the etiological factor analysis, urethral stricture was detected in five patients with both urethral and bladder stones. Three of them had frequently recurrent urethritis and two had a history of endoscopic ureteral stones. These patients underwent internal urethrotomy and endoscopic cystolithotripsy. In addition, bladder neck stenosis was observed in three patients. Two of them had posterior urethral rupture after a fall from a height, and one had a history of open prostatectomy. Endoscopic bladder neck incision and endoscopic cystolithotripsy were performed in these patients. The remaining 19 patients had prostatic hyperplasia (Table 2). A total of six patients underwent open prostatectomy and cystolithotomy. The mean duration of open surgical procedure was $80.43 \pm 19.41$ minutes. The mean prostate volume of these patients was 93.33 $\pm 12.49 \mathrm{~g}$ and the mean stone size was $64.17 \pm$ $7.79 \mathrm{~mm}$. The rest 13 patients underwent transurethral prostatectomy and endoscopic cystolithotomy. The mean duration of endourologic interventions was $55.14 \pm 16.13$ minutes. The mean prostate volume was $60.38 \pm$ $12.66 \mathrm{~g}$ and the mean stone size was $40.1 \pm 11.98$ $\mathrm{mm}$. Patients with bladder stones were treated endoscopically. When they were considered as a whole, the prostate volumes were found to be $47.13 \pm 15.23 \mathrm{~g}$ and stone size to be $33.6 \pm 13.2$ $\mathrm{mm}$. These values were significantly low compared with that of those who underwent open surgery $(p<0.001)$. All stones were completely removed from the patients evaluated in our study. The etiologic factors causing stone formation were treated.

Table 2: Etiological factors

\begin{tabular}{|l|l|l|l|}
\hline Factors & $\mathrm{n}$ & $\%$ & ${ }^{\mathrm{b}} \mathrm{P}$ value \\
\hline Prostatic hyperplasia & 19 & 70.4 & \\
\hline Urethral stricture & 5 & 18.5 & $\mathrm{P}<0.001$ \\
\hline Bladder neck stenosis & 3 & 11.1 & \\
\hline
\end{tabular}

b. Chi square test, *statistically significant

\section{DISCUSSION}

Urinary tract stone disease is the third pathological condition affecting urinary system following urinary infections and prostate diseases (10). The prevalence of urinary stone disease has been increasing in the last 20 years causing the situation to turn into a public health issue that needs to be handled by health professionals. It is closely related to many factors such as geographical region, socio-economic status, genetics and dietary habits (11). The prevalence of urinary system stone varies between $4 \%$ and $20 \%$ in economically strong societies (12). In a study conducted by Akınc1 et al. in 14 different regions 
in our country, the general prevalence of urinary system stone diseases is reported to be $14.8 \%$ and the incidence $2.2 \%$ (13). Uluocak et al. reported the lifetime prevalence of urinary stone disease as $11.42 \%$ in their study performed in our city, Tokat (14).

Bladder stones constitute 5\% of all urinary system stone diseases and are the most common form of lower urinary tract stones. Besides, they account for approximately $1.5 \%$ of visits to urology clinics (15). The clinical presentation of bladder stones varies according to the size, shape and formation rate. Age, general condition and gender of a patient can be counted among other factors affecting this condition. Patients may present with very different symptoms such as acute urinary retention, dysuria, weakening of urine flow, frequent urination, hematuria, nocturia, and sensitivity in the suprapubic region. Despite this, bladder stones may sometimes be found completely incidentally during imaging (7). Clinical findings caused by bladder stones are directly related to patients' age distribution and the anatomy of the urinary system. In one of their studies, Malladad et al. evaluated 42 patients with bladder stones and reported that abdominal pain was the most common presentation with a rate of $71 \%$ (16). In another study, Abarchi et al. evaluated 70 patients with bladder stones and reported that the most common reason for presentation to the clinic was lower urinary tract complaints (67\%) (17). Only patients with acute urinary retention were enrolled in our study, and urinary tract infection was recorded as the most common secondary pathology.

However, life-threatening outcomes associated with bladder stones may be seen, though rarely, especially in patients who remained untreated for a long time. These clinical conditions include renal failure as secondary to urinary retention (18). Similarly, there are studies in the literature reporting that bladder stones may cause spontaneous bladder perforations (19). Clinical studies performed in previous years demonstrate that complicated urinary tract infections appear to be the predisposing factor that should be considered carefully, especially in cases with neurogenic bladder $(8,20)$. In our study, $14.8 \%$ of the patients were diagnosed with renal failure. However, none of the patients had any lifethreatening acute pathology in their clinical follow-up.

Bladder stones are divided roughly into three categories according to their formation which are migrant, primary and secondary $(15,21)$. Migrant bladder stones occur when the stones in the upper urinary tract descend to the bladder, while primary bladder stones are those that arise directly without any anatomic, functional or infectious cause. Primary bladder stones are especially seen in residential areas of lower socioeconomic status. The majority of affected patients are children under 5 years of age. The main risk factors for this important public health problem include low protein diet, dehydration, use of goat milk and poor socioeconomic conditions (22). The most affected regions are the Middle East and North African countries. In terms of stone components, ammonium acid, urate, calcium oxalate, uric acid and calcium phosphate are the most commonly observed major components, respectively (23). As for secondary bladder stones, there are many factors in the etiology such as bladder outlet obstruction, foreign bodies (suture material, catheter), pelvic or gynecological surgeries, chronic bacteriuria, urinary diversions, neurogenic and metabolic disorders $(7,15,21,24-26) .95 \%$ of bladder stones are observed in male patients (27). In women, urethra is short and wide which may be considered as a natural protection mechanism for bladder stone formation. Bladder stones are observed secondary to the growth of prostate gland in men older than 50 years of age, especially those with better living conditions (28). Tzortzis et al. dealt with 31 patients with bladder stones and found the most common etiological factor to be prostatic hyperplasia with a rate of $51.6 \%$. The same study indicated that only $12.9 \%$ of the cases with bladder stones were women (29). A study by Al-Ansari concluded that $3.1 \%$ of the cases consisted of women (30). Sofer et al. revealed that prostatic hyperplasia was the most common pathology $(50 \%)$ in the pathogenesis of stone formation in a similar study including 50 patients with bladder stones (31). Another study by Asci et al. demonstrated that $52.5 \%$ of patients with bladder stones did not have infravesical obstruction. All patients involved in our study were men (32). Etiological factors of the cases were clearly defined, and the most common one was prostatic hyperplasia. Mostly the stones are composed of uric acid in uninfected urine, and struvite in infected urine (33). Some of the bladder stones are radiopaque and can be detected directly on the urinary tract x-ray (27). Nonetheless, urinary ultrasonography and computed tomography are other imaging modalities commonly used in diagnosis. However, definitive diagnosis is made by cystoscopic evaluation (8). In a series of studies including 94 cases, Singh et al. reported that $96.8 \%$ of the stones were observed on direct urinary system 
graphy (34). A similar study stated that $96.9 \%$ of the patients had radiopaque stones (30). In our study, $92.5 \%$ of the cases were observed on direct urinary system graphy in accordance with the literature.

Treatment of bladder stones is vital in terms of clinical findings and secondary pathologies with bladder stones. Among these pathologies, frequently recurrent urinary tract infections take the first place. In addition, chronic urinary retention-induced hydroureteronephrosis and renal failure may also develop in the long term. However, bladder stones can also cause malignant pathologies such as squamous cell carcinoma secondary to deformations in the bladder surface epithelium especially due to chronic irritation.

Many different treatment methods have been described in the treatment of bladder stones. These treatment modalities include extracorporeal shock wave lithotripsy (ESWL), transurethral cystolithotripsy, percutaneous cystolithotripsy, open or laparoscopic cystolithotomy $(15,21)$. In the treatment of bladder stones, it is crucial to eliminate underlying causes as well as stone clearance. ESWL is a widely used treatment modality in the treatment of urinary tract stone disease. Its mechanism is based on the fragmentation of stones via converting sound waves from an external source into shock waves and directing them to the localized stone in the urinary system (35). ESWL is performed in many centers since it does not require anesthesia in patients without any major infravesical obstruction and is practical in use. Delakas et al. reported the overall stone-free rate as $94.2 \%$ in their study on the results of ESWL in bladder stones (36). Similarly, Al-Ansari et al. evaluated 62 cases and reported a success rate of $98.4 \%$ (30). We did not prefer to use the ESWL method clinically in our study, because all patients had presented with acute urinary retention and were catheterized.

Transurethral cystolithotripsy and percutaneous cystolithotripsy are endourological approaches for the treatment of bladder stones. Especially with the common use of holmium laser in many clinics, the success rates of these endourological approaches are markedly increased. Nameirakpam et al. reported a success rate of $100 \%$ in their study evaluating the results of transurethral cystolithotripsy in 85 patients (37). A study performed by Uzun et al. dealt with 37 patients who underwent transurethral holmium laser cystolithotripsy for bladder stones, and $11.1 \%$ of them were reported to have open surgical procedures (38). Postoperative urethral strictures are the most undesirable complications in transurethral cystolithotripsy. Urethral strictures prepare the ground for recurrent bladder stone formation and lead to increased health expenditures as a result of frequent visits to the outpatient clinic. This is directly related to the prolongation of time and inadequate fragmentation of stones. Karami et al. evaluated the results of transurethral cystolithotripsy applied to 48 patients with bladder stones. A detailed analysis of their study reveals that all stones were completely fragmented, and no postoperative stricture was observed in any of the patients (39). Major complications the investigators encountered with can be directly related to the short operation time and full fragmentation of stones. As for our study, the endourological treatment modalities lasted 55 minutes when taken as a whole, and all stones were perfectly fragmented. Although the long-term results were not addressed, we did not encounter any major complications in the intraand postoperative periods. We believe that it is related to the short operation duration and our clinical experiences. We preferred open surgical interventions to prevent long-term urethral damage in patients with large prostate volume and stone load.

Percutaneous cystolithotripsy is one of the most common treatment modalities in patients with bladder stones and a high stone load. In this approach, an Amplatz sheath is placed, and the stone is cleaned with a nephroscope with an appropriate source of energy or grasper/basket catheters. Tzortzis et al. performed percutaneous cystolithotripsy in 31 patients with bladder stones under local anesthesia and reported their success rate as $96.78 \%$. The same study indicated no major complications (29). A similar study by Wollin et al. discussed the results of percutaneous cystolythotripsy in the treatment of bladder stones and reported that none of the patients had major complications and all of them reported complete stone-free rate (40). We did not perform percutaneous cystolithotripsy in patients with high stone load. We believe this is linked to our clinical experience.

The prevalence of benign prostatic hyperplasia has been increasing in our geography in direct proportion to the increasing economic prosperity and life expectancy. In this context, the incidence of secondary health problems caused by benign prostatic hyperplasia is also on the rise. One of them is the increased risk of bladder stone formation due to residual urine volume induced by bladder outlet obstruction. When the 
relationship between prostatic hyperplasia and bladder stone formation is evaluated, the risk of residual urine volume and urinary tract infection is the first in the pathogenesis. This situation serves as a core and leads to small crystalline accumulation in the urine. On the other hand, the prostate volume and the obstruction of the prostate tissue caused by bladder output are correlated with stone dimensions. In our study, it is clearly seen that direct connection has been established. Sarica et al. investigated patients with bladder stones secondary to benign prostatic hyperplasia and reported that the incidence of multiple bladder stones was in the range of 25$30 \%$ in this group of patients (41). In 19 (70.4\%) patients included in our study, prostatic enlargement was observed. Four $(21.1 \%)$ of these patients had multiple bladder stones. Although surgeons previously preferred open surgery techniques in cases of bladder stones with prostatic hyperplasia, increasing endourological innvations have recently led to different approaches in treatment algorithms. In this context, transurethral cystolithotripsy or percutaneous cystolithotripsy are commonly used together with transurethral resection of the prostate (42). In the use of endourological or open operation techniques, surgeon's experience, clinical facilities, stone size and the identified etiologic factors are critical.

Among the limitations can be counted that biochemical analyses of stones could not be conducted due to technical defficiencies, the number of samples was low and the analyses were carried out retrospectively on patient records.

\section{CONCLUSION}

The first step of the treatment algorithms in patients presenting with acute urinary retention is proper drainage of the urinary tract with correct catheterization as an emergency solution. Following this a correct analysis of etiological factors is crucial for patients to receive the right treatment. It should be kept in mind that acute urinary retention can develop due to multifactorial etiology. In this context, we believe that bladder stones should be among the preliminary diagnoses in male patients presenting with acute urinary retention.

\section{REFERENCES}

1. Taşc1 Aİ. Urinary Retention. Turkiye Klinikleri J Surg Med Sci. 2007; 3(20): 37-40.

2. Thomas K, Chow K, Kirby RS. Acute urinary retention: A review of the aetiology and management. Prostate Cancer and Prostatic Diseases. 2004; 7(1): 32-7.

3. Budak S, Yılmaz M, Aydemir H, Köse O, Dilek FH, Adsan Ö. A Rare Cause of Acute Urinary Retention: Retroperitoneal Ganglioneuroma and Concurrent Mediastineal Schwannoma. J Clin Anal Med. 2013; 4(suppl 2): 145-7.

4. Marshall JR, Haber J, Josephson EB. An evidence-based approach to emergency department management of acute urinary retention. Emergency Medicine Practice. 2014; 16(1): 1-20

5. Selius BA, Subedi R. Urinary retention in adults: diagnosis and initial management. Am Fam Physician. 2008; 77(5): 643-50.

6. Shelley H: Cutting for the stone. J Hist Med Allied Sci. 1958; 13:50-67.

7. Hammad FT, Kaya M, Kazim E. Bladder calculi: did the clinical picture change? Urology. 2006; 67(6): 1154-8.

8. Budak S, Sağlam HS, Köse O, Kumsar Ş, Gürdök Budak G, Adsan Ö et al. Acute Renal Failure and Urosepsis Secondary to Giant Bladder Stone in Patient with Spinal Injury. Turk J Phys Med Rehab. 2014; 60 (Supp. 1): 85-8.

9. Cicione A, DE Nunzio C, Manno S, Damiano R, Posti A, Lima E et al. Bladder stone management: an update. Minerva Urol Nefrol. 2018; 70(1): 53-65.

10. Kilciler M, Erdemir F, Bedir S, Çoban H, Erten K, Özgök Y. The Clinical experience with urethral stones and review of the literature. Türk Üroloji Dergisi 2005; 31(3): 389-95.

11. Xu H, Zisman AL, Coe FL, Worcester EM. Kidney stones: an update on current pharmacological management and future directions. Expert Opin Pharmacother. 2013; 14:435-47

12. Trinchieri A. Epidemiology of urolithiasis: an update. Clin Cases Miner Bone Metab. 2008; 5(2): 101-6.

13. Akinci M, Esen T, Tellaloğlu S. Urinary stone disease in Turkey: an updated epidemiological study. Eur Urol. 1991; 20(3): 200-3.

14. Uluocak N, Erdemir F, Atılgan D, Erkorkmaz Ü, Çetin İ, Parlaktaş BS. The prevalence of urinary system stone disease in Tokat province. Turkish Journal of Urology. 2010; 36(1): 81-6.

15. Demirel HC, Dalkılınç A. Urinary Bladder and Urethral Stones. Turkiye 
Klinikleri J Urology-Special Topics. 2016; 9(2): 68-74.

16. Malladad N, Manjunath DA, Anil R, Radhakrishna V. Clinical study and management of vesical calculus. International Surgery Journal. 2018; 5(4): 1-4.

17. Abarchi H, Hachem A, Erraji M, Belkacem R, Outarahout N, Barahioui M. [Pediatric vesical lithiasis. 70 case reports]. Ann Urol (Paris). 2003; 37(3): 117-9.

18. Yoldaş M, Kuvvet Yoldaş T, Türk H, Karabıçak M, Ergani B, Çelik O et al. A giant bladder stone as a cause of acute renal injury: Case report Tepecik Eğit. ve Araşt. Hast. Dergisi. 2015; 25(2): 140-2.

19. Salar R, Özbay E, Karlıdağ İ, Durmuş E, Öncel HF, Özyuvali E et al. Spontaneous Bladder Perforation Due To Giant Bladder Stone: A Case Report Van Tip Derg. 2017; 24(3): 188-190,

20. Jahromi MS, Mure A, Gomez CS. UTIs in patients with neurogenic bladder. Curr Urol Rep. 2014; 15(9): 433.

21. Öztürk $S$, Beyazıt $Y$, Büyükkurt $S$, Gelegen KÖ, Doran Ş. Laparoscopic cystolithotomy and transvaginal extraction for removal of a large bladder stone. Cukurova Med J. 2017; 42(3): 5714.

22. Lal B, Paryani JP, Memon SU. Childhood bladder stones - an endemic disease of developing countries. J Ayub Med Coll Abbottabad. 2015; 27: 17-21.

23. Valyasevi A, Van Reen R. Pediatric bladder stone disease; current status of research. J Pediatr. 1968; 72(4): 546-53.

24. Chen Y, DeVivo MJ, Lloyd LK. Bladder stone incidence in persons with spinal cord injury: determinants and trends, 1973-1996. Urology. 2001; 58: 665-70

25. Stav K, Dwyer PL. Urinary bladder stones in women. Obstet Gynecol Surv. 2012; 67: 715-25.

26. Okeke LI, Takure AO, Adebayo SA, Oluyemi OY, Oyelekan AA. Urethral obstruction from dislodged bladder diverticulum stones: a case report. BMC Urol. 2012; 12: 31.

27. Agarwal A, Sigdel G, KC SR, Shrestha P, Belokar WK. A unusual case of 356 vesical calculii. Journal of College of Medical Sciences-Nepal. 2012; 8: 44-7.
28. Schwartz BF, Stoller ML. The vesical calculus. Urol Clin North Am. 2000; 27: 333-46.

29. Tzortzis V, Aravantinos E, Karatzas A, Mitsogiannis IC, Moutzouris G, Melekos MD. Percutaneous suprapubic cystolithotripsy under local anesthesia. Urology. 2006; 68(1): 38-41.

30. Al-Ansari A, Shamsodini A, Younis N, Jaleel OA, Al-Rubaiai A, Shokeir AA. Extracorporeal shock wave lithotripsy monotherapy for treatment of patients with urethral and bladder stones presenting with acute urinary retention. Urology. 2005; 66(6): 1169-71.

31. Sofer M, Kaver I, Greenstein A, Bar Yosef Y, Mabjeesh NJ, Chen $\mathrm{J}$ et al. Refinements in treatment of large bladder calculi: simultaneous percutaneous suprapubic and transurethral cystolithotripsy. Urology. 2004; 64(4): 651-4.

32. Asci R, Aybek Z, Sarikaya S, Büyükalpelli R, Yilmaz AF. The management of vesical calculi with combined optical mechanical cystolithotripsy and transurethral prostatectomy: is it safe and effective? BJU Int. 1999; 84(1): 32-6.

33. Erdem E, Usta A, Altun E, Karacan M. Giant Bladder Stone, Bilateral Hydronephrosis And Urinary İncontinence; A Case Report And A Review Of The Literature. Balıkesir Medical Journal. 2017; 1(3): 120.

34. Singh P, Singh B, Yedalwar V, Gaharwar APS. Clinico-Bacteriological Study Of Vesical Calculus. J Evolution Med Dent Sci. 2016; 5: 2131-7.

35. Kölükçü E, Kılıç Ş, Parlaktaş BS, Uluocak N, Atılgan D, Alkan E et al. Üst üreter taşlarının tedavisinde vücut dışı şok dalgaları ile taş kırma sonuçlarımız. J Health Sci Med. 2019; 2(1): 13-17.

36. Delakas D, Daskalopoulos G, Cranidis A. Experience with the Dornier lithotriptor MPL 9000-X for the treatment of vesical lithiasis. Int Urol Nephrol. 1998; 30(6): 703-12.

37. Nameirakpam S, Naorem S, Faridi MS, Akoijam KS, Sinam RS. Transurethral Cystolithotripsy of Large Bladder Stones by Holmium Laser as a Day Care Procedure. J Clin Diagn Res. 2016; 10(12): 1-2. 
38. Uzun H, Tomak Y, Zorba OÜ, Bostan H, Kalkan M. Transurethral cystolithotripsy with a ureteroscope under local urethral anaesthesia and sedoanalgesia. Journal of the Pakistan Medical Association. 63(8): 961-4.

39. Karami H, Razaghi MR, Javanmard B, Yaghoob M, Hadad AH, Amani M. Outpatient Transurethral Cystolithotripsy of Large Bladder Stones by Holmium Laser. J Lasers Med Sci. 2016; 7(1): 125.

40. Wollin TA, Singal RK, Whelan T, Dicecco R, Razvi HA, Denstedt JD. Percutaneous suprapubic cystolithotripsy for treatment of large bladder calculi. J Endourol. 1999; 13(10): 739-44.

41. Sarıca K, Baltacı S, Kılıç S, Dinçel S, Şafak M. 371 Bladder Calculi in a Benign Prostatic Hyperplasia Patient. International Urology and Nephrology. 1994; 26: 23-5.

42. Deliktaş H, Çetinkaya M, Şahin H. Comparison between transurethral resection of the prostate and simultaneously performed percutaneous, and transurethral cystolithotripsy. Tepecik Eğit ve Araşt. Hast. Dergisi. 2017; 27(1): $37-41$. 